\title{
What Have They Done to My Song? Recycled Language in Monika Fagerholm's The American Girl
}

\author{
Julia Tidigs
}

"This is where the music begins" (Fagerholm 2009a, 1). So reads the very first sentence of Finland-Swedish ${ }^{1}$ author Monika Fagerholm's novel Den amerikanska flickan (2004; Translated as The American Girl 2009). On the first pages of the novel, we find ourselves on the brink of the 1970s, and the American girl herself, Eddie de Wire, finds herself at the amusement park on Coney Island in New York. She enters a self-recording booth and sings, a capella:

Titta mamma, de har förstört min saing.

Det låter inget vidare. Det gör det inte. Men det betyder ingenting.

Titta, mamma, vad de har gjort åt min saing. (Fagerholm 2005, 8)

Look, Mom, they've destroyed my song.

It does not sound very good. It really does not. But it does not mean anything.

Look, Mom, what they've done to my song. (Fagerholm 2009a, 2)

J. Tidigs $(\bowtie)$

University of Helsinki, Helsinki, Finland

(C) The Author(s) 2020

185

K. Malmio, K. Kurikka (eds.), Contemporary Nordic Literature

and Spatiality, Geocriticism and Spatial Literary Studies,

https://doi.org/10.1007/978-3-030-23353-2_9 
This phrase, which appears here in two slightly different versions, returns throughout the novel. It is the novel's phrase above all other, and it is symptomatic in several ways: because it involves music; because it involves translation; because it travels between characters; because reiteration with variation is the way this novel works; and because the phrase comes from somewhere else-it is borrowed from Melanie Safka's song "What Have They Done to My Song, Ma"—and, through this intermedial connection, stands in relation to faraway places. It is the leitmotif of The American Girl.

I am not the first to pay attention to the song of the American Girl. Several scholars have discussed the role of music and/or reiterations in the novel. In the recent anthology of Fagerholm scholarship Novel Districts (2016), edited by Kristina Malmio and Mia Österlund, Lena Kåreland has treated the musical references of the novel as a form of "intermedial transformations" 2 and the role of music for the novel's tone as well as structure: Fagerholm "writes like a composer,"3 Kåreland $(2016,27)$ declares. In her research on Fagerholm, Maria Margareta Österholm has mentioned the "sabotaged songs" $(2012,109)$ in The American Girl, and discusses the music in terms of gurlesque (Österholm 2016, 103-4, 111). Kaisa Kurikka (2016) has explored intertextual references and musical figures in connection to Fagerholm's use of repetition with variation in the novel Diva (1998) from the perspective of style and minor literature. Jenny Holmqvist (2016) has treated the use of repetition in The American Girl, and Bo G. Jansson (2013, 88-91) discusses Fagerholm's musical references and the use of repetition as postmodern traits which-among other thingslink the novel's language to oral cultural expressions. Moreover, Anna Helle examines The American Girl as postmodern melodrama, as well as the links between death and affect in the novel and for its readers (Helle $2013,2016)$. Helle draws attention to the use of reiteration with variation on the level of both phrase and story, and has also touched upon the importance of music and its connection to melodrama in the novel. ${ }^{4}$

Regardless of the ample previous attention that has been given to these features of Fagerholm's works, I do believe that there is more to explore, especially concerning the circumstance that many of the references and quotes in The American Girl are translated from other languages than the language of the novel, Swedish. Some of these quotes and referencesthough not all-are repeated. Some of them-though not all-are musical references. From the perspective of literary multilingualism, the translated quotes-often musical, often reiterated-appear to be on the edge, or rather, on the border zone of multilingualism, as I will show in the final 
part of this chapter. This is a zone where music, intermediality, translation, and multilingualism are in contact. ${ }^{5}$ An added emphasis on translation, I argue, can further illuminate the linguistic practices of Fagerholm's novel, not least the spatiality of its language.

At a glance, it can seem that questions of language and translation are painfully absent in spatially oriented literary studies. In literary multilingualism studies, however, the use of multilingualism in the literary construction of different geographical places (and their inhabitants) have been put under investigation (see e.g., Tidigs 2009, 2014; Malmio 2011; Wirth-Nesher 2006; Pultz Moslund 2011). More importantly for the purposes of this chapter, literary multilingualism studies have paid ample critical attention to what, to a high degree, is a distinct spatial anchoring of languages in Western society during the last couple of centuries, namely nationalist language ideology. Just as conceptions of space are historically situated, as Robert T. Tally Jr. (2013, 17-42) has delineated, the manner in which language has been conceptualized in spatial terms as well as in relation to geographical places, has altered historically.

The birth of the modern nationally oriented conception of language involved a spatialized conception and anchoring of language in at least two distinct, yet related ways. The first involves the individual, the socalled native speaker, whose body becomes a container for the mother tongue. As Jacques Derrida (1998) and Yasemin Yildiz (2012, 6-14)-following Derrida-have emphasized, the nationalist conception of the mother tongue relies upon the idea of ownership of the native language, an ownership passed down from birth (through the mother). The "native" language of the individual is imagined to be spatially contained inside a body, and thus anchored physically in that body from birth. In this chapter, however, I will, through my reading of Fagerholm's novel, contrast this rather stationary conception of linguistic and emotional bindings with a conception of language that places movement at the center.

The other way nationalist language ideology has anchored language spatially is in terms of (geographical) space. Nationalism's motto of one language, one people, and one territory inscribes a mutual, fixed, relationship between language and geographical space through the (presumed) speakers of the "mother tongue" who reside there. Again, the idea of ownership is important, namely the collective ownership of the geographical nation(-state) on behalf of the people. Languages are imagined to reside in and intrinsically belong to a territory (in contrast to simply being spoken, to a various degree, by individuals who can stay in or move to or 
from a geographical area and also use languages in areas other than those where a language is most commonly spoken). It is significant that Gilles Deleuze and Félix Guattari (1986), in their attempt to make visible the processual, dynamic, power-fused, and unstable character of this spatial anchoring of language and place, use terms that contain the notion of territory: deterritorialization and reterritorialization. Although this chapter does not employ Deleuze and Guattari's terminology throughout, my investigation of literary language likewise puts a focus on movement and the temporal instability of spatio-linguistic constellations.

In Cities in Translation, Canadian scholar Sherry Simon explores the multilingualism of cities such as Montreal and Barcelona. Simon urges us to listen to the city: "Much of the abundant literature in recent decades has emphasized the visual aspects of urban life. And yet the audible surface of languages, each city's signature blend of dialects and accents, is an equally crucial element of urban reality" (Simon 2012, 1). This is in line with Bertrand Westphal's reminder of taking a "polysensuous approach" to geocritical studies: "Geocriticism promotes the empire of the senses, a polysensuous approach to places-places meaning concrete or realized spaces. Most of the time, places are perceived with our eyes, but it seems most appropriate to diversify sensing to include the sounds, smells, tastes, and textures of a place" (Westphal 2011, xiv). Although Simon's object of investigation is a non-literary city and mine is a literary text, I am inspired by both the implicit polysensuous approach of her study and her focus on the "puntos suspendidos, the areas of negotiation, the spaces where connections are created through translation" (Simon 2012, 2). Thus, I aim to explore Fagerholm's translated and borrowed phrases as precisely such polysensuous connective points where the Swedish of the novel is in dynamic contact with different languages outside of it.

In this chapter, I will first read Fagerholm's novel through its use of borrowed and translated phrases. What role do they play in the novel that they traverse? Thereafter, I will continue with a discussion of how this use of language affects the novel's readers by facilitating a reading/sounding experience and, by way of extension, challenges dominant conceptions of linguistic spatiality in Finland-Swedish literature.

Before these questions of multilingualism, translation, and spatiality are explored, however, the very practical conundrum that the question of translation poses for this chapter needs to be addressed. Most of the quotes that comprise the topic of this chapter come from English and appear in Swedish translation in Fagerholm's Den amerikanska flickan. Discussing 
them in English, and with references to the English translation, The American Girl, makes this multilingual factor almost invisible and difficult to grasp. I try to tackle this problem by offering the references to the novel in both Swedish and English; however, nothing can alter the fact that some readers see a text in Swedish with translated quotes in it, and some readers see an English text with English quotes in it. I will return to this question of translation and re-translation at the end of the chapter.

\section{A Rumble of Borrowed Words and Sounds}

Monika Fagerholm (b. 1961) is probably the most prominent writer in contemporary Finland-Swedish literature; she is also highly successful in Sweden, where she has received several of the most prestigious literary awards. ${ }^{6}$ Fagerholm can also be considered a feminist cult writer with her coming of age novel Diva (1998). The novel The American Girl (2004) is, among many things, a story of love, friendship, and play between two girls, Sandra Wärn and Doris Flinkenberg, who become obsessed with the mysterious death of the American Girl, Eddie. Eddie is said to have drowned in a lake close to where Sandra and Doris live, but at the beginning of the novel, her body has not yet been found. In the end, it is the boisterous yet fragile Doris who takes her own life, while Sandra grows up to be a singer.

Multilingualism and linguistic heterogeneity has formed an important feature of Fagerholm's literary works since her debut with the story collection Sham in 1987. In The American Girl alone, there is much to explore: from the estrangement of Swedish by syntactic means that is Fagerholm's tour de force (see Dahl 2015), through the more "traditional," lexical multilingualism with occasional lines in English, German and French, and her sporadic use of dialectally marked language, to parodic episodes marked by "Swenglish" ( see Fagerholm 2005, 343-7; this kind of language disappears in English translation, see Fagerholm 2009a, 355-9). For the purposes of this chapter, however, I will confine myself to the translated phrases.

As Kaisa Kurikka and Anna Helle have shown, the repetition of borrowed phrases, worn and torn when they travel between characters, is a central feature of Fagerholm's writing (Kurikka 2016, passim.; Helle 2013, 13ff.; Helle 2016, 84, 91). The many quotes from books, films, and songs are most prominently featured in Diva and in the diptych "The End of the Glitter Scene," comprising The American Girl from 2004 and Glitterscenen from 2009 (translated as The Glitter Scene, 2010). Diva is 
replete with quotes and intertextual references - one that has achieved cult status is the line from an Inger Lundmark poem, "Det enda som hjölper mot tankar är hud" ("The only help against thoughts is skin"). In Diva, an afterword with the heading "Loans, quotations" informs readers of the origin of some of the borrowed phrases, although the attribution is sometimes vague. ${ }^{7}$ Not all loans are declared; for instance, the important recurring phrase "Kom upp och se mig, fä mig att le" is not revealed to be a translation of "Make Me Smile (Come Up and See Me)" by Steve Harley \& Cockney Rebel.

In The Glitter Scene repetition is driven to extremes in terms of both phrase reiteration and storytelling. In the Swedish original, Glitterscenen bears the subtitle "och flickan hon går $i$ dansen med röda gullband"s ("And the girl joins the dance with red golden ribbons"; the subtitle is lacking from the English translation) and is meta in relation to its stylistic and narrative devices; it comments repeatedly on its own method-through music: "The folksong. A repetition in time and space. Such a different way of understanding time" (Fagerholm 2010, 80; "Folkvisan. En upprepning i tid och rum. Ett sådant annorlunda sätt att uppfatta tiden" Fagerholm 2009b, 69) (see also Kåreland 2016, 27).

If The Glitter Scene is a folksong, then an accurate description of The American Girl would perhaps be "sabotaged folk rock." In The American Girl, reiteration is crucial: the story of the mysterious death of the American girl Eddie de Wire is told time and again, in different versions. Musical references play an even greater role than in Diva, and in contrast to the folksong obsession of The Glitter Scene, the multilingual aspect is more prominent in The American Girl. To name but a few examples: the Tennessee Williams quote "Ingen kände min ros i världen utom jag" (Fagerholm 2005, 14-15; "Nobody knew my rose of the world but me," Fagerholm 2009a, 8-9); “Jag är INTE kär. Det är bara ett tokigt skede jag genomlever nu" (Fagerholm 2005, 389, see also 373) from 10cc's old hit "I'm not in love ... it's just a silly phase I'm going through," (Fagerholm 2009a, 402, see also 386); "Hjärtat är en hjärtlös jägare" (Fagerholm 2005, 14, 2009a, 8), a variation of Carson McCullers's The Heart is a Lonely Hunter; "Bergen lever upp till tonerna av musik" (Fagerholm 2005, 247; "The hills are alive with the sound of music," Fagerholm 2009a, 254), the lead song of the musical The Sound of Music. Also noteworthy in connection to this is the circumstance that Eddie's distant relation, whom she boards with, is called Fröken ("Miss") Andrews. ${ }^{9}$ There is Doris's nickname Doris Dag, which in English turns her into "Doris Day." And when 
I read the phrase "Bär Doris over mörka vatten" (Fagerholm 2005, 15, 239), it always brings to mind the Swedish version of Simon and Garfunkel's "Bridge over Troubled Water," "Som en bro över mörka vatten ska jag bära dig" ("I will carry you/Like a bridge over troubled waters"). ${ }^{10}$

There are many more of these kinds of phrases, including many Swedish quotes and song lyrics, which are recycled in the novel: the folksong "Jag gick mig ut en afton uti en lund så grön" (Fagerholm 2005, 309, see also 309-17; "I walked out one evening, out into a grove so green," Fagerholm 2009a, 319); Swedish early twentieth century poet Dan Andersson's "Omkring tiggarn från Luossa" that was made into a hit in the 1970s by popular Swedish folk group the Hootenanny singers (Fagerholm 2005, 243, 2009a, 250); “ÄR DET VERKLIGEN FREEED VI VILL HA ... TILL VARJE TÄNKBART PRIS?" (Fagerholm 2005, 217; "IS IT REALLY PEACE WE WANT, AT ANY CONCEIVABLE COST?," Fagerholm 2009a, 241), the chorus of the hit "Fred" ("Peace") by leftist Swedish "progg" group Hoola Bandoola Band. ${ }^{11}$ Doris's boyfriend Micke Friberg repeats "Ingen kan älska som vi," the title of an iconic Swedish youth film, admittedly from the 1980s, featuring the overplayed pop song "Inga kan älska som vi," "No one can love like us" (Fagerholm 2005, e.g., 318; Fagerholm 2009a, e.g., 328).

In the author's acknowledgments at the end of the novel, Fagerholm states that she has "at times taken the liberty of translating the lines from well-known musical pieces and from pop songs on my own, so as to be appropriate for the novel's plot" (Fagerholm 2009a, [509]). Here, Fagerholm explicitly acknowledges that song lyrics have been borrowed, incorporated, and translated, and that translation involves activity, choice, and metamorphosis.

\section{A Song Fragment Travels Through a Novel}

The entire 500-page novel starts "This is where the music begins" (Fagerholm 2009a, 1). This is, I argue, nothing less than a reading instruction: This is music. Read this book as you would listen to a song. Listen to it. If we do, what happens then to the song of the American girl?

In the introductory scene we are placed on Coney Island. Thus, even when reading the novel in Swedish readers know that the language surrounding the American girl, Eddie, is English: the italicized English line "Do you need a place to crash?" in the Swedish original also shows this 
(Fagerholm 2005, 7, 2009a, 1). Readers are told that Eddie sings, and the song lines are also rendered in italics: "Look, Mom, they've destroyed my song. (...) Look, Mom, what they've done to my song" (Fagerholm 2009a, 2). ${ }^{12}$ At this moment, however, the experiences of readers diverge. For when reading this, some readers will hear in their minds the following song lyrics, accompanied by Melanie Safka's voice:

Look what they've done to my song, ma

Look what they've done to my song

Well it's the only thing that I could do half right

And it's turning out all wrong, ma

Look what they've done to my song (Safka 2015)

Melanie Safka's hit "What Have They Done To My Song, Ma," from 1970, has lent its first line to Fagerholm. For some readers-and I here speak of "real" readers, physical beings that experience the world through their senses, beings who have ties to different languages and different fields of association-for some of the novel's readers, the phrase is also a translated phrase, a phrase to recognize. Simultaneously as they/we read in Swedish, they/we hear this song, and not only the words but also melody, voice, accompaniment.

Here it is worthwhile to point out that Safka's lyrics themselves involve variation and translation, since the song is bilingual. The sixth verse is a translation of the first verse into French:

Ils ont changé ma chanson, ma

Ils ont changé ma chanson

C'est la seule chose que je peux faire

Et çe n'est pas bon, Ma

Ils ont changé ma chanson. (Safka 2015)

At this point in the discussion it is important to note that the Melanie Safka connection in The American Girl is not a riddle waiting to be solved. ${ }^{13}$ The phrase is not effective only in the light of its intermedial connection. Even if read without Melanie Safka, without a perspective of multilingualism, translation, or intermediality, and only as a Swedish phrase within the context of the novel, the phrase still constitutes reiterated, varied, and recycled language-language one can do something with. 
What, then, is the presence of this song of the American girl in the novel? Eddie, in Coney Island, records it. The recording is brought to "the District" in Finland. There, the song is present as one of many fragments of names, words, and music that make up the history of the District. ${ }^{14}$ The boy Bengt remembers the phrase from his talks with Eddie (Fagerholm 2005, 30, 2009a, 25). Doris and Sandra listen to Eddie's recording. When Sandra "hummed and spoke like Eddie had spoken," the song line is once again present: "Look, Mom, they've destroyed my song" (Fagerholm 2009a, 178). Doris "ALMOST started humming the Eddiesong, the American girl's song. She almost thought about telling-everything" (Fagerholm 2009a, 325). She tries to explain to her boyfriend that which Sandra would have understood directly, that the song is "A song that someone wants to sabotage" (Fagerholm 2009a, 325). Sandra, in turn, imagines her mother Lorelei Lindberg "singing the Eddie-song" (Fagerholm 2005, 462, 2009a, 478). The song wanders between characters who sing and speak its words differently, and for whom it functions differently. "Sandra sang and when she sang she felt it so clearly and strongly, she was not pretending to be the American girl, she was her" (Fagerholm 2009a, 174). The song is borrowed, and it has metamorphic qualities - to repeat, with variation, gives the characters possibilities to transform. But at the end of the novel, the song dies. This time, Sandra is in the self-recording booth on Coney Island and when she is about to sing she is lost for words, sees herself from the outside, and the whole situation becomes absurd. ${ }^{15}$

Recurring, commented upon, and often written in italics, the song about the destroyed song is present throughout the novel, and has the ability to express and forebode. Among other things, the central word of "mamma," "ma," 16 draws attention to the ominous figure of the mother in the novel. Österholm has mentioned that the song expresses that which Doris and Sandra cannot speak of in direct words: how they both were abandoned by their mothers (Doris's mother who mistreated her badly, Sandra's mother who left when she and Sandra's father divorced). ${ }^{17}$ The song of the American girl/Melanie Safka, however, also addresses itself directly to a mother, and is both foreboding and haunting. ${ }^{18}$ The premature deaths of Eddie and Doris are connected to the song as well as with mothers, foster mothers, or mother figures. One could call "the mother" a black hole at the center of "The End of the Glitter Scene": she is a key figure associated with the role of victim as well as perpetrator,-a figure whose actions incite devastating chain reactions but also a figure that is 
always seen from a great distance. The perspective with Fagerholm is always that of the daughter, but the recurring song lyrics mean that the novel is haunted by the figure of the mother.

\section{Reading the Novel as Song}

The phrase from Melanie Safka's song is important for the novel when read solely within the frame of the book, namely for its characters and its theme, but it also alludes to an entire song. What happens with the reading of the book if we listen to that song?

For readers who hear the song when reading The American Girl, it sets the tone for the entire novel. In the song, there is a discrepancy between the light melody and the sinister lyrics, with metaphors that are taken literally and become grotesque. ${ }^{19}$ This macabre effect is especially evident in the second verse:

Look what they've done to my brain, ma

Look what they've done to my brain

Well they picked it like a chicken bone

And I think I'm half insane, ma

Look what they've done to my song (Safka 2015)

The girl in the song has had her brain picked until she is half insane-the simile "picked it like a chicken bone" is impossible not to imagine visually. The American Girl is a novel about stories: necessary stories, subversive stories but also dangerous stories, that can pick on your-or Doris'sbrain 'til you're half insane.

Further on in the song, the third-to-last verse goes:

Look what they've done to my song, ma

Look what they've done to my song, ma

Well they tied it up in a plastic bag and turned it upside down, ma

Look what they've done to my song (Safka 2015)

As early as in the first verse, the song is an object that can be destroyedthat is also present in Fagerholm's Swedish translation. In the second-tolast verse, things are taken even further: here, the song is tied up in a plastic bag and turned upside down, sparking associations to asphyxiation. In the novel, the sabotage of a song, albeit a different one than Safka's, 
becomes literal when Doris shoots the doorbell of Sandra's house to pieces. This is the doorbell that plays "Nach Erwald und die Sonne. Die Sonne. Die Sonne. Die Sonne" 20 (Fagerholm 2009a, 68), a phrase that is closely connected to the stories Sandra tells about how her mother was swept away to the alps in her lover Heintz-Gurt's helicopter, stories with big holes in them but that keep picking on Doris's brain (Fagerholm 2009a, 83-9).

An additional important aspect of turning song into object is that the musical references in the book necessarily involve the transformation of transient auditory phenomena-words being sung-that are turned visual and objectified as printed letters on the page when written down. As such, the fragments of songs point toward an oral linguistic realm outside of the text, a realm with which the text is in contact. ${ }^{21}$

Here I return to the third verse:

I wish I could find a good book to live in

Wish I could find a good book

Well if I could find a real good book

I'd never have to come out and look at

Look what they've done to my song (Safka 2015)

"I wish I could find a good book, to live in"-in several ways, this is just what happens. "There was this mushy side to Doris Flinkenberg. And in Doris Flinkenberg's head it was accompanied above all by different melodies that she snapped up a bit here and a bit there" (Fagerholm 2009a, 219-20). ${ }^{22}$ Doris Flinkenberg, who lived in a realm of easy-listening pop and the stories of crime magazines, gets to live on in Sandra's songs of their games, friendship, and love when Sandra becomes a singer (see Österholm 2016, 111). For Doris the world turned out to be unlivable, a circumstance closely connected to the novel's theme of stories as necessary for survival and simultaneously potent and potentially lethal. But there is yet another dimension to living in the book: Fagerholm has given Safka's song a good book to live in, and not only that, she has placed the song center stage.

In media theorist Lars Elleström's terminology, the translated phrase from Melanie Safka's "What Have They Done to My Song, Ma" can be labeled a "simple representation of a media product" (Elleström 2014, 29). ${ }^{23}$ Only the first line of Safka's song is present in Fagerholm's text, its origin is not mentioned and the song not described. However, this 
apparent "simplicity" does not equal lack of effect: as Elleström notes, "[o]ccasionally, for some perceivers, media representations such as these are not at all simple because they trigger far-reaching associations and interpretations" (Elleström 2014, 29). Indeed, above I have explored the significance of such associations and interpretations for the reading of the novel. Moreover, the form of the reference does not decide its relationship to the novel as whole: while the phrase itself is simple, its deployment in the novel, characterized by repetition with variation, is highly complex. The novel's use of the song is, I argue, only in small part to be viewed as a representation of a specific media product and more as a stylistic and narrative vehicle, a motor for its storytelling and transformation of language.

\section{LANGUAGE From ELSEWHERE}

In the last part of the chapter I want to discuss what the translated and often repeated phrases do for the experience of reading the novel, as well as for the spatial anchoring-or, rather, dislodgement, of its language.

Borrowed scraps of language crisscross The American Girl, moving from character to character, from place to place, being recycled for new purposes. The translated phrases emphasize language as sprung from use, language as something collective, already used, already borrowed, always in transformation (see Deleuze and Guattari 2011, 8, $111 \mathrm{ff}$.). There is no reiteration without variation and transformation. ${ }^{24}$ Already on the first page, "Look, mom, they've destroyed my song" is borrowed from somewhere else, Melanie Safka's song. And Eddie sings a capella-itself a variation. Of course, this inevitable mutability is not exclusive for intermedial references: it concerns all language. The translated quotes - that pop out, feel strange, feel familiar-only display this ever more clearly; they turn up the volume, so to speak.

In Born Translated: The Contemporary Novel in an Age of World Literature (2015), Rebecca L. Walkowitz turns traditional conceptions of original preceding translation, of what a literary work is, who its readers are, and what reader competence is all about, upside down. According to Walkowitz $(2015,4)$, literature can be "born translated" in different ways: it can be a question of works that are, for example, "written for translation, in the hope of being translated, but they are also often written as translations (...). (...) They are also frequently written from translation." A feature of so-called born-translated literature is that it "approaches 
translation as medium and origin rather than as afterthought. Translation is not secondary or incidental to these works. It is a condition of their production" (Walkowitz 2015, 3-4). This perspective, I argue, can illuminate a central aspect of The American Girl and its language.

In the beginning of The American Girl, there was translation: to take something that transforms in the process, and to extract something new from it. With translation and variation, Fagerholm can transport a tone, evoke a specific historical moment, awaken associations and moods among her readers, but also make the Swedish of her novel strange and new. This is a subtle affair. Walkowitz $(2015,32-3)$ emphasizes that the borntranslated literature of late modernity is not defined by particularist language meant to be decoded by select, "competent" readers. ${ }^{25}$ Instead, "contemporary novels have developed strategies of multilingualism designed for the foreign, nonfluent, and semifluent readers who will encounter them" (Walkowitz 2015, 44), for example the "narration" of languages, where the presence of foreign languages is signaled without the languages being represented directly in the text. The American Girl does something similar in its involvement with other languages: the translated phrases can be "decoded" in the sense that readers can recognize them from elsewhere, but the understanding or enjoyment of the novel is not dependent on readers doing so, nor do they make the novel less "approachable." The intertextual and intermedial connections are, however, a sign of the novel being born in translation. The American Girl begins in several languages, in several places, in several media.

Yet another effect of this overflow of references, clichés, reiterations, is that we start reading phrases that are not borrowed from another book, or film, or song, as if they were loans, as if they were translations, as if they were handed down, collective, recycled language-which in the end they are.

Walkowitz notes the way multilingualism and translation challenge the spatio-linguistic constructs of nationalism, where language and territory are locked together in ordered pairings: "Once literary works begin in several languages and several places, they no longer conform to the logic of national representation" (Walkowitz 2015, 30). In the early twentieth century, a Finland-Swedish language norm was established in linguist Hugo Bergroth's very influential Finlandssvenska. Handbok till undvikande av provinsialismer $i$ tal och skrift (1917, "Finland-Swedish: A Handbook for the Evasion of Provincialisms in Speech and Writing"). Bergroth's ideal was a Finland-Swedish as similar to the Swedish spoken and written in Sweden as possible, and he explicitly urged writers of poetry 
and prose to learn to conform to this norm in their works. For a great part of the following century, the central question regarding the linguistic heterogeneity of Finland-Swedish literature was: How is Finland to be depicted entirely in the Swedish language, when life in Finland is rarely lived entirely (or even mostly) in Swedish? (See Ekman 2011, 34-47). When literary language did diverge from the Finland-Swedish language norm, either by inclusion of regionalisms or Finnish words or phrases, this linguistic heterogeneity was most often interpreted as a sacrifice of universal comprehensibility for the sake of authenticity, that is, showing readers how Finland-Swedes "really speak" (see Tidigs 2016).

Fagerholm's language, however, transgresses the paradigm of authenticity versus comprehensibility. Previously, Kristina Malmio (2012) has shown how Fagerholm opened up Finland-Swedish prose to the world with the help of pop culture in Diva. ${ }^{26}$ In The American Girl, the transatlantic connection is visible from the start, both in the story and in the novel's language. This language, with its multitude of references, strange syntax and occasional Swenglish, is always language from elsewhere. For The American Girl - transatlantic, heterogeneous but in a non-organic manner-there is no given, no seemingly "organic" connection between word and place. The language of the novel is not about realistic depiction of life along the Finnish south coast; rather, it concerns tone, atmosphere, and time.

As mentioned at the beginning, the recycled language of the novel can be viewed as belonging to a border zone of literary multilingualism. Strictly speaking, in the case of the translated phrases, no foreign language is present on the page. It is, however, possible to read this kind of literary language as Yasemin Yildiz reads literal translations. In Beyond the Mother Tongue: The Postmonolingual Condition, Yildiz (2012, 144, 168) discusses the literary use of literal translations in Emine Sevgi Özdamar's works as a form of multilingualism that is simultaneously visible and invisible, and as a form that transforms both of the involved languages. In The American Girl, the translation from English transforms Swedish, and the Swedish translation is able to extract something new from the English.

Furthermore, the seeming lack of multilingualism, that is, the explicit presence of a foreign language, is valid only if we look solely at the book page and not consider the actual reading experience. In an article on intermedial connections between music and literature, Axel Englund has stressed how "the arts (...) exist simultaneously in the mind of the percipient" (Englund 2010, 79). If we consider the literary work not only 
as the text on the page but as the text in contact with a reader, that is, that the literary work comes into being in the meeting of text and reader, then we do find ourselves in a multilingual border zone. Then, The American Girlcomes into existence in the meeting between text and all the texts and songs_-among them Melanie Safka's - that are opened up inside readers. Elleström $(2010,23)$ has acknowledged the "inner sound experiences produced by the mind" of the reader of poetry. When coming into contact with intermedial references, the fact that the text consists only of printed words in Swedish, and that Eddie is said to sing a capella, does not stop some of the readers from hearing the music. In instances such as these, these sound experiences in the minds of readers concern not only words but also music, and not only the tenor of a voice but also accompaniment, rhythm, and so on. Readers/listeners do not disjoin sound from semantics in an abstract way, when they read and hear a song in their heads. Just as Sandra hears the echo of the voice of the deceased Doris in her head, just as the "mushy side" of Doris was accompanied by melodies, readers hear echoes of schlagers, pop songs, and folksongs. Through the presence of the song references, the literary work becomes a multilingual soundscape, created by and for every reader-listener in an endless series of slightly different versions.

\section{Continuous Transformation}

In this chapter I have explored the presence of translated and transformed song lyrics in The American Girl through a lens of translation, multilingualism, and spatiality. The borrowed, traveling, and collectively repurposed fragments of songs and phrases from English emphasize language as variation and transience. As Daniel Heller-Roazen expresses this everfleeting movement of language, in dialogue with Montaigne and Dante:

The beginning and the ending of a tongue are perhaps best grasped in the terms afforded by Montaigne. They can be seen as nothing other than two moments in the course of the "continual variation" by which every language "runs away" from its speakers and "deforms itself," (...).

(...) Hence the vanity of all attempts to slow or stop the fleeting course of languages. Whether they are nationalist or international, philological or ecological, such projects are united in the belief that speech is an object in which linguists can, and must, intervene to recall and conserve the identity from which it seems to be departing. In their aim to hold on to the forms of 
speech a tongue has already cast off, such efforts are futile at best. One way or another, a tongue will continue in our time to change "by half," running away and deforming itself as it does, for a language, as Dante wrote, "can never remain the same," and, whether we like it or not, it will continue "every day," in the words of the essayist [Montaigne], to slip out of our hands. (Heller-Roazen 2005, 74-5)

In its emphasis on repetition with variation, Fagerholm's novel challenges the postulates of nationalist thinking about language and literature, forsaking the idea of linguistic stability so crucial to it. On account of its continuous reliance on translation, it also challenges the literary ideal of originality also crucial to modern literature. The translated fragments demonstrate language not as individual expression of the writer's soul but instead as a common resource of already used sentences, ready to be put to use, put into circulation again.

In its insistence on mobility and translation, Fagerholm's novel is distinctly late modern. The transatlantic language of the novel is on the move between people and places, not locked in a relationship to any certain place or to the body of any certain speaker. In The Sociolinguistics of Globalization, Jan Blommaert $(2010,2)$ acknowledges how globalization has "dislodged" "the traditional concept of "language." The artifactualized image of language of modernity must, according to Blommaert, be replaced with "a view of language as something intrinsically and perpetually mobile, through space as well as time, and made for mobility" (xiv)just like the language of Fagerholm's novel. Late modernity, and The American Girl, lets language have free reign with its focus on use instead of expression of identities, national or individual (in the form of the "mother tongue").

As mentioned in the introduction, The American Girl does not only begin in translation, it is also a novel that has been translated-into English among other languages. In translation, things start to happen with the originally translated phrases. In the case of the American girl's song, it is not only Fagerholm's translation-in-original, but also Katarina E. Tucker's English translation that make use of variation:

She pushes Record and then she sings.

Look, Mom, they've destroyed my song.

It does not sound very good. It really does not. But it does not mean anything.

Look, Mom, what they've done to my song. (Fagerholm 2009a, 2) 
This is not the wording of Safka's song; when seemingly "returning" to English, the phrase does not return to its "original" wording. ${ }^{27}$ The translation clearly privileges Fagerholm's Swedish version and not the English "original" phrases that were borrowed into it. I do not know if Tucker was aware of the connection to the Melanie Safka song when she translated these lines and chose "Mom" instead of "ma"; in the translator's acknowledgments at the end of The American Girl, Fagerholm's cooperation is mentioned (Fagerholm 2009a, [511]). In the end, however, it is strangely effective. When Walkowitz advocates a new definition of world literature for the late modern era, this is not the world literature dependent on nineteenth-century conceptions of it as "a container for various national literatures" that in themselves are seen as countable and separate entities, and as a literature which privileges a so-called primary or native audience (Walkowitz 2015, 30). Instead, Walkowitz argues for world literature as a "series of emerging works, not a product but a process" and which "privileges target: the analysis of convergences and divergences across literary histories" (Walkowitz 2015, 30). ${ }^{28}$ She stresses: "a work may be produced several times, through adaptation, rewriting, and translation" (Walkowitz $2015,31)$.

Seen from this perspective, Tucker's translation continues the work that Fagerholm's original work was already employed with: repetition, with variation. Fagerholm's Swedish translations are both same and different; they have already liberated themselves from the English "source." In English once more-as in translation into other languages-the phrases continue this movement whilst simultaneously carrying their past with them, like a note, or an echo.

\section{Notes}

1. Finland-Swedish/Finland-Swede (Swedish: finlandssvensk) is the accepted term for Swedish speakers from Finland. The coining of finlandssvensk in the 1910s was part of the formulation of national consciousness on behalf of Finland's Swedish-speaking minority, to a large extent as a result of the Finnish national awakening during the latter half of the nineteenth century (see Mustelin 1983).

2. Kåreland highlights the importance of intermediality in Fagerholm's works: "Intermedial transformations, that is the relationship and interaction between structures and devices from different art fields such as visual art, film and music, are typical of Fagerholm's authorship" (Kåreland 2016, 27). 
3. "She transforms literature into music and the importance of music is prominent in her writing as an underlying structure. She writes like a composer, using a broken prose, where the sentences sometimes are unfinished and intertwined. In her texts, as in music, one theme attaches to another and the chords are repeated. Circles and repetitions of phrases and words go in and out of each other as themes in a piece of music" (Kåreland 2016, 27).

4. Helle primarily connects repetition with variation in the novel to the effect of ambiguity (Helle 2013, 13, 2016, 84, 91). On music and melodrama, see, for example, Helle $(2016,86)$.

5. Because I aim to examine the connections between translation and intermediality, it is important to make a distinction between the concepts: in this chapter, translation refers solely to the relationship between languages, such as Swedish and English. It is not used to describe intermedial relationships, such as the presence of song lyrics in a literary text or other kinds of intermedial connections. Thus, intermediality refers to the presence of musical references in the novel while translation refers to such references having been translated from one language to another.

6. In 2005, Fagerholm received the August Prize (Augustpriset) and the Göteborgs-Postens Literature Prize as well as the Aniara Prize for The American Girl, and in 2016, Fagerholm was the recipient of the Swedish Academy Nordic Prize, also referred to as "the little Nobel." She has also been the recipient of several Finnish literature awards.

7. For example, "har Jouko Turkka sagt nångång nånstans" ("has Jouko Turkka said sometime somewhere," Fagerholm 1998, [447]). Jouko Turkka (1942-2016) was a prominent Finnish theater director and writer.

8. The phrase comes from a well-known Swedish singing game, danced and sung at Midsummer or Christmas celebrations.

9. The name Fröken Andrews bears associations to the actress Julie Andrews, who not only played the lead role in Sound of Music but also in the stage production of the musical My Fair Lady (in the motion picture, Eliza Doolittle is played by Audrey Hepburn, who also played Holly Golightly in the adaptation of Truman Capote's Breakfast at Tiffany's, to which there are also Eddie references in The American Girl). In My Fair Lady, an important feature are sentences used for language instruction; in Fagerholm's novel, Fröken Andrews makes sisters Rita and Solveig repeat such phrases in order to learn English (Fagerholm 2005, 435, 2009a, $450)$.

10. "Carry Doris over troubled water" (Fagerholm 2009a, e.g., 9); "Carry Doris over dark waters" (Fagerholm 2009a, 245).

11. On the album, the song is called "Fred (till [for] Melanie)"-band member Mikael actually wrote the song as a response to the song "Peace Will Come (According to Plan)" by none other than Melanie Safka (www. 
mikaelwiehe.se/komment_fred.htm). "Progg" refers to a left-wing and anti-commercial musical movement in Sweden during the 1960s and 1970 s and should not be confused with progressive rock in general.

12. "Titta mamma, de har förstört min sång."; "Titta, mamma, vad de har gjort àt min sång" (Fagerholm 2005, 8).

13. The Melanie Safka connection has been mentioned by, for example, Helle $(2016,86-7)$ and Österholm $(2016,105)$; the song was also sung onstage in the dramatic adaptation of The American Girl at Åbo Svenska Theater (Turku Swedish Teater) in 2007.

14. "The District and its history are also in the Winter Garden. Like pictures on the walls, names and words, music. (...) Look, Mom, they've destroyed my song" (Fagerholm 2005, 15, 2009a, 9).

15. "She starts singing. An old song. The Eddie-song, which it was once called./Look, Mom, what they've done to my song./They've destroyed it./ But it is so stupid. Suddenly she has forgotten the words. The words to THAT song, it is almost unbelievable!/She stops singing, stops completely. Suddenly she sees herself from outside./What in the world is she doing standing there in the booth howling, all alone?/It is absurd" (Fagerholm 2009a, [502]). The heading of this chapter is called "The Day the Music Died. And I Started Living."

16. Melanie Safka's song uses "Ma"; Katarina E. Tucker's English translation of the novel most often employs "Mom."

17. The song "is a trigger for Sandra's transformation to the Marsh Queen but the song also expresses many of the unspoken experiences Sandra and Doris have in common, such as unresolved relationships to the adult women in their lives; they have both been abandoned by their mothers" (Österholm 2016, 105).

18. Helle $(2016,91)$ mentions the foreshadowing capacity of repetition in the novel, but does not address the example of the American Girl's song in this context.

19. See Helle, whose opinion of the lyrics differs from my own. In Helle's view, Safka's song is not particularly sad, but in the context of The American Girl the words sound sinister (Helle 2016, 87).

20. "Nach Ehrwald und die Sonne" is a cabaret number by legendary Swedish performer Povel Ramel.

21. Bo G. Jansson also mentions the song lyrics as a connective link between the text and oral cultural expressions (Jansson 2013, 91).

22. On the over-sentimentality of Doris, see Helle $(2016,94)$.

23. The distinction between a "simple" and a "complex" representation of a media product is not clear-cut. While Elleström describes the former as for example, a text that "briefly refers to a particular song" (Elleström 2014, 29 ), the latter "may be focused on a variety of characteristics: from formal 
and more abstract traits to features that one tends to relate to content" (Elleström 2014, 31).

24. See Kurikka $(2016,49)$ on repetition in Diva: "Each time the phrase 'the cradle of Western culture' is used, its meaning is changed, while still maintaining the previous uses; thus, it becomes the source of a series of differences and repetitions. The only element that remains the same is the act of repetition. These repetitions can be conceptualized as ritornellos, refrains that bring about the rhythm and melodies of writing and simultaneously assemble various territories."

25. According to Walkowitz $(2015,32-3)$, who refers to Doris Sommer, "The exemplary works of non-translation studies tend to feature idiosyncratic diction, portmanteau words, or phrases that gather several national languages into a single sentence. (...) They are born untranslatable in the sense that they do not travel well and in fact often resist it."

26. Malmio specifically mentions how "Diva breaks the limits of national literature" through "the use of the 'unnatural' possibilities offered by American popular culture, and of science fiction" (Malmio 2012, 90).

27. A similar process has affected the $10 \mathrm{cc}$ quote, where the adjective "silly" (in the song) has gone via "tokigt" in Den amerikanska flickan (Fagerholm 2005,389 ) to "crazy" in The American Girl (Fagerholm 2009a, 402).

28. The traditional conception of world literature that Walkowitz suggests a departure from in contrast "privileges source: distinct geographies, countable languages, individual genius, designated readers, and the principle of possessive collectivism" (Walkowitz 2015, 30).

\section{REFERENCES}

Blommaert, Jan. 2010. The Sociolinguistics of Globalization. Cambridge: Cambridge University Press.

Dahl, Alva. 2015. I skriftens gränstrakter. Interpunktionens funktioner $i$ tre samtida svenska romaner. Uppsala: Uppsala Universitet.

Deleuze, Gilles, and Félix Guattari. 1986. Kafka: Toward a Minor Literature. Translated by Dana Polan. Minneapolis and London: University of Minnesota Press.

- 2011 [2004]. A Thousand Plateaus: Capitalism and Schizophrenia. Translated by Brian Massumi. London and New York: Continuum.

Derrida, Jacques. 1998. The Monolingualism of the Other or The Prosthesis of Origin. Translated by Patrick Mensah. Stanford, CA: Stanford University Press.

Ekman, Michel. 2011. Må vi blicka tillbaka mot det förflutna. Svenskt och finskt hos åtta finlandssvenska författare 1899-1944. Helsingfors: Svenska litteratursällskapet i Finland.

Elleström, Lars. 2010. The Modalities of Media: A Model for Understanding Intermedial Relations. In Media Borders, Multimodality, and Intermediality, ed. Lars Elleström, 11-48. New York: Palgrave Macmillan. 
2014. Media Transformation: The Transfer of Media Characteristics Among Media. New York: Palgrave Macmillan.

Englund, Axel. 2010. Intermedial Topography and Metaphorical Interaction. In Media Borders, Multimodality, and Intermediality, ed. Lars Elleström, 69-80. New York: Palgrave Macmillan.

Fagerholm, Monika. 1998. Diva: en uppväxts egna alfabet med docklaboratorium (en bonusberättelse ur framtiden). Helsingfors: Söderströms.

- 2005. Den amerikanska flickan. Stockholm: Albert Bonniers förlag.

- 2009a. The American Girl. Translated by Katarina E. Tucker. New York: Other Press.

- 2009b. Glitterscenen. Och flickan hon går $i$ dansen med röda gullband. Helsingfors: Söderströms.

- 2010. The Glitter Scene. A Novel. Translated by Katarina E. Tucker. New York: Other Press.

Helle, Anna. 2013. Tulkinnallinen horjuvuus ja affektit. Kuolema Monika Fagerholmin Amerikkalaisessa tytössä ja Säibkenäyttämössä. Avain 1: 5-22.

- 2016. When Love and Death Embrace. Monika Fagerholm's The American Girl and The Glitter Scene as Postmodern Melodrama. In Novel Districts: Critical Readings of Monika Fagerholm, ed. Kristina Malmio and Mia Österlund, 83-98. Helsinki: Finnish Literature Society.

Heller-Roazen, Daniel. 2005. Echolalias: On the Forgetting of Language. New York: Zone Books.

Holmqvist, Jenny. 2016. 'Skott, jag tror jag hör skott.' Bruket av repetition i Monika Fagerholms roman Den amerikanska flickan. Tidskrift för litteraturvetenskap 3-4: 79-95.

Jansson, Bo G. 2013. Ljuga vitt och brett utan att ljuga. Den svenska prosaberättelsen $i$ den postmoderna skärmkulturens tidevarv: filosofisk grund, innehåll och form. Falun: Högskolan Dalarna.

Kåreland, Lena. 2016. Re-Imagining Girlhood. The Revision of Girls’ Books in Monika Fagerholm's DIVA and The American Girl. In Novel Districts. Critical Readings of Monika Fagerholm, ed. Kristina Malmio and Mia Österlund, 25-37. Helsinki: Finnish Literature Society.

Kurikka, Kaisa. 2016. Becoming-Girl of Writing. Monika Fagerholm's DIVA as Minor Literature. In Novel Districts: Critical Readings of Monika Fagerholm, ed. Kristina Malmio and Mia Österlund, 38-52. Helsinki: Finnish Literature Society.

Malmio, Kristina. 2011. Ut i vida världen. Flerspråkighet i några finlandssvenska romaner på 1990- och 2000-talen. In Både och, sekä että. Om flerspråkighet. Monikielisyydestä, ed. Heidi Grönstrand and Kristina Malmio, 293-317. Helsingfors: Schildts.

- 2012. Phoenix-Marvel Girl in the Age of fin de siècle. Popular Culture as a Vehicle to Postmodernism in Diva by Finland-Swedish author, Monika 
Fagerholm. In Nodes of Contemporary Finnish Literature, Studia Fennica Litteraria 6, ed. Leena Kirstinä, 72-95. Helsinki: Finnish Literature Society.

Moslund, Sten Pultz. 2011. The Presencing of Place in Literature: Toward an Embodied Topopoetic Mode of Reading. In Geocritical Explorations: Space, Place, and Mapping in Literary and Cultural Studies, ed. Robert T. Tally Jr., 29-43. New York: Palgrave Macmillan.

Mustelin, Olof. 1983. 'Finlandssvensk' - kring ett begrepps historia. In Svenskt $i$ Finland 1. Studier $i$ spraik och nationalitet efter 1860, ed. Max Engman and Henrik Stenius, 50-70. Helsingfors: Svenska litteratursällskapet i Finland.

Österholm, Maria Margareta. 2012. Ett flicklaboratorium i valda bitar. Skeva flickor $i$ svenskspråkig prosa fràn 1980-2005. Stockholm: Rosenlarv förlag.

- 2016. The Song of the Marsh Queen. Gurlesque and Queer Desire in Monika Fagerholm's Novels The American Girl and The Glitter Scene. In Novel Districts: Critical Readings of Monika Fagerholm, ed. Kristina Malmio and Mia Österlund, 99-116. Helsinki: Finnish Literature Society.

Safka, Melanie. 2015 [1970]. Candles in the Rain. Talking Elephant Records.

Simon, Sherry. 2012. Cities in Translation: Intersections of Language and Memory. London and New York: Routledge.

Tally, Robert T., Jr. 2013. Spatiality. London and New York: Routledge.

Tidigs, Julia. 2009. 'Here I Am at Home - Here I Am in a Foreign Land'. Multilingualism, Modernism and (De)Territorialization in the Works of the Finland-Swedish Writer Elmer Diktonius. In Europa! Europa? The AvantGarde, Modernism and the Fate of a Continent, ed. Sascha Bru, Jan Baetens, Benedikt Hjartarson, Peter Nicholls, Tania Ørum, and Hubert van der Berg, 359-372. Berlin and New York: Walter de Gruyter.

- 2014. Att skriva sig över språkgränserna. Flerspråkighet $i$ Jac. Abrenbergs och Elmer Diktonius prosa. Åbo: Åbo Akademis förlag.

- 2016. Litteraturens språkvariation, kritiken och det finlandssvenska rummets gränser. Kim Weckströms Sista sommaren, Kjell Westös Drakarna över Helsingfors och debatten om Finlandiapriset 1996. In Språkmöten i skönlitteratur. Perspektiv på litterär flerspråkighet, ed. Siv Björklund and Harry Lönnroth, 55-72. Vasa: VAKKI Publications.

Walkowitz, Rebecca L. 2015. Born Translated: The Contemporary Novel in an Age of World Literature. New York: Columbia University Press.

Westphal, Bertrand. 2011. Foreword. In Geocritical Explorations: Space, Place, and Mapping in Literary and Cultural Studies, ed. Robert T. Tally Jr., ix-xv. New York: Palgrave Macmillan.

Wiehe, Mikael. Fred (Till Melanie). www.mikaelwiehe.se/komment_fred.htm.

Wirth-Nesher, Hana. 2006. Call It English: The Languages of Jewish American Literature. Princeton: Princeton University Press.

Yildiz, Yasemin. 2012. Beyond the Mother Tongue: The Post-Monolingual Condition. New York: Fordham University Press. 
Open Access This chapter is licensed under the terms of the Creative Commons Attribution 4.0 International License (http://creativecommons.org/licenses/ by $/ 4.0 /$ ), which permits use, sharing, adaptation, distribution and reproduction in any medium or format, as long as you give appropriate credit to the original author(s) and the source, provide a link to the Creative Commons licence and indicate if changes were made.

The images or other third party material in this chapter are included in the chapter's Creative Commons licence, unless indicated otherwise in a credit line to the material. If material is not included in the chapter's Creative Commons licence and your intended use is not permitted by statutory regulation or exceeds the permitted use, you will need to obtain permission directly from the copyright holder.

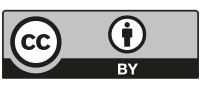

